\title{
The Effect of Small Scale Topographic Gradient on the Distribution and Community Utilization of Indigenous Woody Species in a Lowland Dryland Environment, Lokapel Area, Turkana, Kenya
}

\author{
Francis Mwaura ${ }^{*}$, Joel Wamalwa ${ }^{2}$, Tiffany Mwake ${ }^{1}$ \\ ${ }^{1}$ Department of Geography \& Environmental Studies, University of Nairobi, Nairobi, Kenya \\ ${ }^{2}$ County Government of Kakamega, Kakamega, Kenya \\ Email: *mwauraf@uonbi.ac.ke
}

How to cite this paper: Mwaura, F., Wamalwa, J. and Mwake, T. (2017) The Effect of Small Scale Topographic Gradient on the Distribution and Community Utilization of Indigenous Woody Species in a Lowland Dryland Environment, Lokapel Area, Turkana, Kenya. Natural Resources, 8, 592-609. https://doi.org/10.4236/nr.2017.89038

Received: January 8, 2017

Accepted: September 11, 2017

Published: September 14, 2017

Copyright $\odot 2017$ by authors and Scientific Research Publishing Inc. This work is licensed under the Creative Commons Attribution International License (CC BY 4.0).

http://creativecommons.org/licenses/by/4.0/

(c) (i) Open Access

\begin{abstract}
The landscape of Lokapel is characterized by a distinctive dryland vegetation, whose distribution is influenced by altitudinal change and the use of woody species by the local community along $100 \mathrm{~m}$ altitudinal gradient from River Turkwel $(662 \mathrm{~m})$ to Lokapel Hill $(764 \mathrm{~m})$. The paper undertakes the following: (a) to establish the influence of elevation on woody vegetation species distribution in different landscapes in the area and (b) to assess the consumptive and non-consumptive uses of woody vegetation in the area by the local community and determine the utility patterns along the altitudinal gradient. A total of forty three species of woody plants were identified with the top five species in terms of widespread distribution being; Indigofera cliffordearia (10 percent), Acacia tortilis (9.8 percent), A. nubica (8.8 percent), Balanites rotundifolia (6.3 percent), and Acacia reficiens (5.4 percent). The local people used the indigenous woody species to address a total of 18 demands including provision of livestock fodder, household construction, bio-energy, and herbal medicines. The variation in woody species and their uses showed the total number of woody species distribution has the highest peak around $680 \mathrm{~m}$ but altitude accounted only for 51 percent of the variation in woody species.
\end{abstract}

\section{Keywords}

Tropical Drylands, Landscape Gradient, Woody Species Distribution, Vegetation Uses 


\section{Introduction}

Drylands are defined as areas of extreme aridity and low water moisture. They are part of the rangeland environments which receive an average annual rainfall of less than $600 \mathrm{~mm}$, and whose fragile soil is unsuitable for agriculture but whose vegetative cover is suitable for livestock production. Rangelands are defined as areas carrying natural or semi-natural vegetation which provides a habitat suitable for herds of wild or domestic ungulates. Drylands occur in most continents of the world and are estimated to cover some 4.5 billion hectares or 61 million square kilometers or just over 47 percent or one-fifth of the earth's land surface but are mostly widespread in the tropic \& sub-tropic regions of the world. Water shortage is therefore one of the greatest challenges facing dryland areas all over the world. In Africa, recurrent droughts that may persist for several consecutive years are the rule, not the exception in the drylands and these conditions are expected to deepen with the on-going climate change.

The global importance of dryland environments cannot be ignored because they dominate the world's terrestrial environment. Drylands provide fodder for about 360 million cattle and over 600 million sheep and goats and sustain up to 100 million pastoral people. In Africa, drylands constitute approximately 70 percent of the total land surface thereby making it one of the dryland continents of the world. Within the Eastern Africa region, approximately 83 percent of the land is characterized by Drylands. This includes approximately 35 percent of Uganda, 74 percent of Tanzania, and 85 percent of Kenya.

Drylands in Kenya cover about $467,200 \mathrm{~km}^{2}$, which is over 80 percent of the country's total landmass of $584,000 \mathrm{~km}^{2}$. These areas include arid districts that receive marginal rainfall as low as $150 \mathrm{~mm}$ per annum and the semi-arid districts which receive between $400 \mathrm{~mm}$ and $800 \mathrm{~mm}$. However, inter-annual rainfall in the drylands, which are also commonly known as arid and semi-arid lands (ASALs), can vary significantly from $50-100$ percent in the arid zones and $20-30$ percent in the semi-arid zones. Table 1 highlights the general characteristics of the dryland ecological zones (NCAPD 2010). The drylands in Kenya are classified into four key ecological zones, namely zones IV, V, VI and VII [1] [2]. In

Table 1. The dryland ecological zones in Kenya.

\begin{tabular}{|c|c|c|c|c|c|}
\hline Zone & Climate & $\begin{array}{l}\text { Average annual rainfall } \\
\qquad(\mathrm{mm})\end{array}$ & $\begin{array}{l}\text { Moisture index } \\
(\%)\end{array}$ & Landcover & Land use \\
\hline IV & Savanna & $600-1100$ & $40-50$ & $\begin{array}{l}\text { Dry woodland, bushland and } \\
\text { grassland }\end{array}$ & $\begin{array}{c}\text { Ranching, pastoralism (cattle, sheep, goats), } \\
\text { wheat, barley, sunflower, maize, cotton, } \\
\text { cashew nuts, cassava }\end{array}$ \\
\hline $\mathrm{V}$ & Semi-arid & $450-900$ & $25-40$ & Bushland & $\begin{array}{c}\text { Ranching, pastoralism cattle, sheep \& goats, } \\
\text { sorghum, millet. }\end{array}$ \\
\hline VI & Arid & $300-550$ & $15-25$ & Bushland and shrubland & Pastoralism \& ranching (sheep \& goats), \\
\hline VII & Very arid & $150-350$ & $<15$ & Desert scrub & $\begin{array}{l}\text { Nomadic pastoralism } \\
\text { (goats, sheep, donkeys and camels) }\end{array}$ \\
\hline
\end{tabular}


the face of climate change, the drylands are expected to experience a significant reduction in rainfall by up to 20 percent and a temperature rise of $4{ }^{\circ} \mathrm{C}$ [3].

The drylands of Kenya are characterized by a rich array of natural resources, most of which are largely un-documented due to the general remoteness as well as many years of both political and socio-economic negligence of the area. Although these areas are home to about 9.9 million people or approximately 34 percent of the country's population, 75 percent of its wildlife population, over 80 percent of the country's eco-tourism interests, and account for almost $60-70$ percent of the nation's livestock, they have continued to lag behind other parts of Kenya. Pastoralists in the drylands of Kenya are associated with the production of about 9.7 million beef cattle, 9.6 million goats, 8.3 million sheep and 0.8 million camels [4]. On the overall, this represents about 60 percent of the country's cattle, 70 percent of the sheep and goats and 100 percent of the camels in the country. In addition, the ASALs provide over 67 percent of the red meat consumed in the country and contribute 10 percent of the national GDP [4].

Despite this, the drylands in Kenya are generally considered as low potential environments which have suffered many years of political and economic negligence. They continue to lag behind the rest of the country in terms of infrastructure and most forms of social services. The areas are heavily infested by poverty, disease, famine, malnutrition, illiteracy and insecurity. The ASAL region can however be regarded as the forgotten giant of Kenya for several reasons including its expansive size, its strategic position as a gateway to critical neighboring countries such as Uganda, South Sudan, Ethiopia, Somalia and Tanzania and its untapped economic potential much of which is yet to be sufficiently prospected. It would be unstrategic for a country to continue economically disregarding such a large part of districts. This is bound to change following recent discovery of large quantities of oil in the Turkana region [4].

Apart from other resources, woody biodiversity is an important asset for dryland environments all over the world because it serves as an important life support for people, livestock and wildlife. Woody species in the drylands usually serve as an important driving force for the local economy especially through the livestock sector. In recent years, the interest on dryland biodiversity has emerged in Kenya, not only due to the oil discovery but also following fruitful bio-prospecting ventures which have discovered highly competitive natural herbal products mainly with the aid of local indigenous knowledge [4]. This includes a wide range of popular herbal products for both local and international market developed using Aloe material for which Kenyan drylands have over forty different species. The extraction of gum Arabica for industrial use predominantly from Acacia senegal is another example. Unfortunately, the intellectual property rights have totally ignored the huge contribution from the local indigenous knowledge in the identification, discovery and commercialization of natural products from dryland biodiversity. These examples indicate the huge economic potential lying within the drylands but this will only be fully unlocked 
through more intensive studies on dryland biodiversity especially woody vegetation.

Elevation, aspect, and slope are the three main topographic factors that control the distribution and patterns of vegetation in mountain areas. Among these three factors, elevation is considered as the most important [5] [6]. Elevation change affects nearly all aspects of the ecosystem because of the myriad influences on microclimate and geomorphology related to increasing elevation, including increased precipitation, decreasing air temperatures, shorter growing season, different soil-forming conditions and weathering regimes, increased geomorphic patterns and related phenomenal [7]. Elevation along with aspect and slope in many respects determines the microclimate and thus large-scale spatial distribution and patterns of vegetation [8] [9] [10] [11]. The distribution of human settlements and vegetation utilization patterns can therefore be influenced by the topography in terms of the available opportunities in the woody species along the landscape catena. Studies on the impact of topographic gradient on dryland vegetation distribution patterns can explain human settlement and resource utilization patterns. But such studies are not very common in the developing region especially Africa.

In Kenya, the available literature on dryland environments has mainly focused on dryland communities, natural resources and conflicts [12]-[17], dryland pastoralism [18] [19] [20], the impact of droughts [21] [22], land use and land degradation [23] [24]. Other dryland biodiversity-related studies are focused on resource property rights, ecological productivity [25], wildlife issues [26], and herbivore impact on dryland vegetation [27] [28]. However, it is quite clear from the profiles of available literature on dryland areas, such environments have been less attractive for scientific investigations and are very much the same picture even with planners, policy makers and most of the general public. Although some studies have considered the impact of topographic gradient on woody species diversity, the integration of this on the social dimension especially the influence of human settlements and resource utilization has not been widely considered especially in Africa.

This study was intended to inform the 2003-2005 UNDP/GEF/GoK Indigenous Vegetation Project (IVP) in Kenya by examining the woody vegetation characteristics in the Lokapel area which is within the Katilu IVP Pilot Site in Turkana. The aim was to undertake a systematic assessment of woody species composition in the Lokapel area using the landscape approach by considering a topographic profile from the downstream Turkwel River to the upstream Lokapel Hills which is located about $30 \mathrm{~km}$ west of Lokichar. The river and hill are two critical island ecosystems with a lot of human interest in the area due to the scarcity of resources and vulnerable livelihoods. The specific objectives of the study were: (a) to establish the influence of elevation on woody vegetation species distribution in different landscapes in the area and (b) to assess the consumptive and non-consumptive uses of woody vegetation in the area by the local community and determine the utility patterns along the altitudinal gradient. 


\section{Materials and Methods}

The study site was located at Lokapel sub-location Katilu Division in the lower southern part of Turkana district. The site was about $35 \mathrm{~km}$ from the Lokichar market centre off the Lodwar-Kitale highway towards Turkwel River (Figure 1). The area is mainly dominated by ecological zones V and VI according to the classification of rangelands [1]. The study site stretched from the banks of River Turkwel, which flows into Lake Turkana, and extends to the area around the Lokapel Hills. The mean annual rainfall in the area is about $300-600 \mathrm{~mm}$ with frequent and prolonged droughts as in other drylands of Kenya. The Lokapel Hill $(870 \mathrm{~m})$ serves as the main water catchment for the local area with storm runoff flowing from the hills into the Turkwel River during rainy seasons. Due to the physiographic setting of the area as well as overgrazing, storm runoff has gradually established numerous landmark ephemeral runoff drains also known as laggas such as the Lokapel and Akareterete which flow from the Lokapel Hills towards the river (Figure 1). The main occupants of the area are the Turkana, a central Paranilotic-speaking society living almost exclusively in the Turkana District of Kenya where they mainly practice nomadic pastoralism. They keep sheep, goats, donkeys and camels in large numbers. The local communities in Lokapel are settled in communal village or Manyatta at around $670 \mathrm{~m}$. Woody

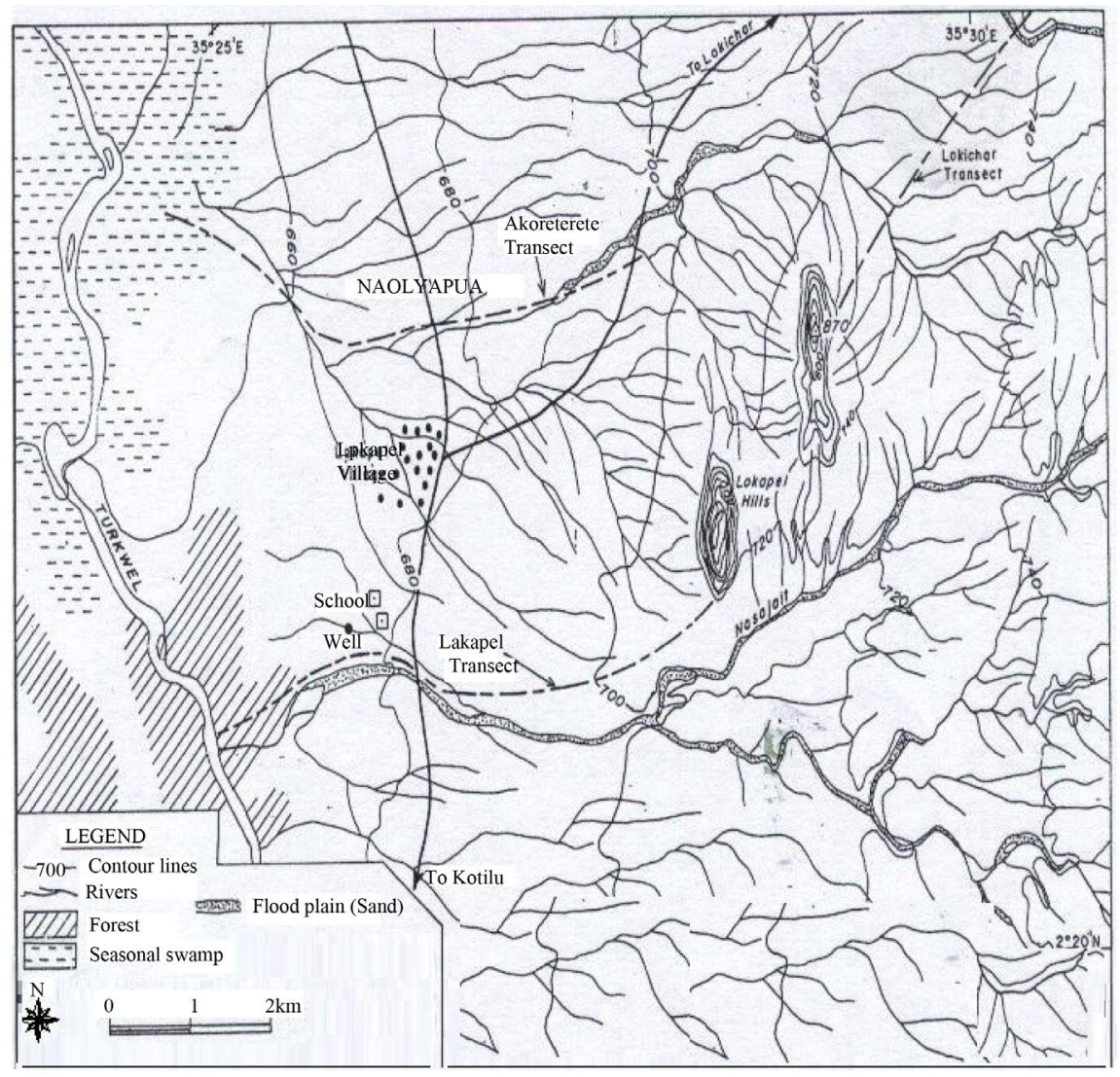

Figure 1. The characteristics of the study area and location of sampling transects. Source: Researcher 2003. 
vegetation is a precious environmental asset in the area because it sustains the livestock sector which is the mainstay of the local economy in the area. Woody biodiversity also provides construction material for human and livestock shelter as well as firewood and traditional medicines to the local community which is highly isolated from the other parts of the country.

Three baseline transects of $2-4 \mathrm{~km}$ were set approximately $1-3 \mathrm{~km}$ apart for woody vegetation sampling using the GPS compass in order to maintain a consistent direction eastwards as shown in Figure 1. The baselines for transects 1 and 2 were configured along the Lokapel and Akareterete laggas whose courses were conspicuous and easy to follow and these transects are therefore referred by those names (Figure 1). Both Lokapel and Akareterete laggas were running from the downstream Turkwel River to the upstream Lokapel Hills. They formed critical lifeline zones for the local people and livestock throughout the year as sources of water, fodder and bio-fuel. Transect 3 was set as a control transect by having a western orientation from the Lokapel Hills towards the Lokichar market centre located away from the Turkwel River. The control transect was also not running along a lagga like the other two transects. The area also had marginal hydrological influence from the Lokapel Hills.

The Point-Centered Quarter (PCQ) method was used in the three transects to assess the woody vegetation characteristics and their utilization [2]. The PCQ is a distance method of sampling woody vegetation characteristics such as species composition, height and utilization. The distance interval between the vegetation observation points was measured using a GPS and generally varied between 200 $\mathrm{m}$ and $500 \mathrm{~m}$ depending on the degree of environmental variability in terms of altitudinal gradient and change in vegetation cover as deduced through visual assessment. The interval was shortened in the transect sections of high variation and lengthened in sections of low variation.

At each PCQ observation point, the ground area was subdivided into four sampling quarters using a PCQ stick. At each reference point, altitude readings were recorded using a Garmin GPS handset. The nearest woody species from the central control reference point in each quarter was identified in the field using local indigenous knowledge and latter in the office using taxonomic guides. A local team of field assistants consisting of a group of local elders were engaged throughout the sampling process to provide the local names for all the selected woody species and a checklist of all the community uses associated with each of the 4 nearest-neighbour woody species per quarter. A total of 51 sites and 204 PCQ reference sites were examined including 21, 20 and 10 sites each in transects 1,2, and 3, respectively. Data analysis for the study included computation of summary statistics, mainly involving the calculation of means and frequencies. Species frequency was computed as the total appearances of a given species divided by the total appearances for all species in the three transects. Advanced analysis was mainly restricted to analysis of variance (ANOVA) and discriminant analysis. 


\section{Results}

The elevation records for the three transects indicated an overall range of altitudinal gradient of $102 \mathrm{~m}$ stretching from $662 \mathrm{~m}$ (River Turkwel) to $764 \mathrm{~m}$ (Lokapel Hills). The lowest point at $662 \mathrm{~m}$ was recorded in Transect 2 while the highest at $764 \mathrm{~m}$ was recorded in the north eastern foot slope of the Lokakel Hills in Transect 3. This meant that approximately 60 percent of the landscape in the study area was below $700 \mathrm{~m}$ above sea level which means that most of the area is a lowland environment.

An overall and integrated total of forty three species of woody plants were identified and recorded within the three transects which mostly comprised trees, bushes and shrubs. Thirty four species were recorded in Transect 1, 29 in Transect 2 and 14 in Transect 3. Table 2 shows the overall species characteristics. The top ten species in terms of widespread distribution were Indigofera cliffordearia (10 percent), Acacia tortilis (9.8 percent), A. nubica (8.8 percent), Balanites rotundifolia (6.3 percent), Acacia reficiens (5.4 percent), Acalypha fruitcosa (5.4 percent), Hyphaene compressa (4.4 percent), Boscia coriascea (4.1 percent), Lycium europaeum (3.4 percent), and Salvadora persica ( 3.4 percent) Table 2 below. The distribution indicates that the area was characterized by Acacia bushland. The lower number of species in Transect 3 was attributed to the number of observation points in this control transect. The lower diversity of wood species in this transect was also attributed to the rocky conditions and lower moisture levels in the areas outside the lagga environment.

Table 2 shows the spatial distribution of woody species in the area. The key woody species in the high ground areas included Indigofera cliffordearia, Balanites rotundifolia, and Acacia reficiens. The most common woody species in the low ground areas included Acalypha fruitcosa, Boscia coriascea, Hyphaene compressa, Lycium europaeum and Salvadora persica. Acacia tortilis was one of the most widespread woody species in both low-lying and high ground landscapes. Acacia nubica which manifested an invasive tendency was mainly restricted to the middle area between Turkwel River and the Lokapel Hills especially around the Lokapel village which was heavily overgrazed and with clear signs of soil degradation.

The analysis of change in species distribution by topographic gradient showed the total number of woody species distribution has the highest peak around 680 $\mathrm{m}$ although altitude only accounted for 51 percent of the variation in woody species. On the overall, there was a decline in the number of species with increasing altitude as shown in Figure 2. Consequently, it appeared that the Lokapel Hill did not have a sufficiently strong environmental command in terms of rainfall and soil characteristics to influence the woody biodiversity as in the case of the Turkwel River. The analysis of variance (ANOVA) indicated significant variation in number of species and their use by the local people. However, the degree of variation was higher for the uses of woody species at $\mathrm{F}=0.781(\mathrm{P}>$ 0.007). 
Table 2. A checklist of woody species and their general characteristics.

\begin{tabular}{|c|c|c|c|c|c|c|}
\hline \multirow[b]{2}{*}{ Woody species } & \multirow[b]{2}{*}{ Local name } & \multicolumn{3}{|c|}{ Abundance according to total count } & \multirow[b]{2}{*}{$\begin{array}{l}\text { Total } \\
\text { count }\end{array}$} & \multirow[b]{2}{*}{$\begin{array}{c}\text { Total frequency } \\
(\%)\end{array}$} \\
\hline & & $\begin{array}{c}\text { Transect } 1 \\
\text { Lokapel lagga }\end{array}$ & $\begin{array}{c}\text { Transect } 2 \\
\text { Akareterete lagga }\end{array}$ & $\begin{array}{c}\text { Transect } 3 \\
\text { Lokichar } \\
\text { lagga }\end{array}$ & & \\
\hline 1. Abutilon fruticosum & Ekwanga & 1 & 0 & 0 & 1 & 0.5 \\
\hline 2. Abutilon hirtum & Ekwanga & 1 & 1 & 0 & 2 & 1 \\
\hline 3. Acacia elatior & Esanyanait & 0 & 1 & 0 & 1 & 0.5 \\
\hline 4. Acacia mellifera & Ebenyo & 1 & 0 & 0 & 1 & 0.5 \\
\hline 5. Acacia nubica & Epetet & 2 & 16 & 0 & 18 & 8.8 \\
\hline 6. Acacia reficiens & Eregae & 3 & 3 & 5 & 11 & 5.3 \\
\hline 7. Acacia Senegal & Ekunoit & 1 & 2 & 3 & 6 & 3 \\
\hline 8. Acacia tortilis & Ewoi & 11 & 7 & 2 & 20 & 10 \\
\hline 9. Acalypha fruitcosa & Eteteleit & 4 & 7 & 0 & 11 & 5.3 \\
\hline 10. Asparagus $s p$ & Esikarakiru & 3 & 0 & 0 & 3 & 1.4 \\
\hline 11. Balanites pedicellaris & Elamach & 1 & 1 & 0 & 2 & 1 \\
\hline 12. Balanites rotundifolia & $E b e i$ & 4 & 1 & 8 & 13 & 6.3 \\
\hline 13. Barlearia eranthemoides & Logolito & 2 & 1 & 1 & 4 & 2 \\
\hline 14. Boscia coriascea & Edung & 4 & 5 & 0 & 9 & 4.1 \\
\hline 15. Cadaba farinosa & Ereng & 0 & 1 & 0 & 1 & 0.5 \\
\hline 16. Calotropis procera & Lomedotin & 6 & 0 & 0 & 6 & 3 \\
\hline 17. Commiphora brucea & Etesiro & 0 & 1 & 1 & 2 & 1 \\
\hline 18. Commiphora cuneata & Lolewi & 0 & 2 & 0 & 2 & 1 \\
\hline 19. Commiphora schimperi & Echokokile & 0 & 1 & 0 & 1 & 0.5 \\
\hline 20. Cordia sinensis & Ekwangorom & 1 & 1 & 0 & 2 & 1 \\
\hline 21. Euphorbia cuneata & Edome & 1 & 0 & 2 & 3 & 1.4 \\
\hline 22. Ficus sycamorous & Echokoki & 1 & 0 & 0 & 1 & 0.5 \\
\hline 23. Grewia tenax & Echoke & 1 & 3 & 2 & 6 & 3 \\
\hline 24. Helliotropium longiflorum & Engomo & 3 & 4 & 0 & 7 & 3.4 \\
\hline 25. Hyphaene compressa & Ekamasune & 4 & 5 & 0 & 9 & 4.4 \\
\hline 26. Indigofera cliffordearia & Eengol & 7 & 4 & 10 & 21 & 10 \\
\hline 27. Indigofera spinosa & Emaritoit & 2 & 0 & 0 & 2 & 1 \\
\hline 28. Indigofera swaziensis & Emekwi & 1 & 2 & 1 & 4 & 2 \\
\hline 29. Lycium europaeum & Ochor & 3 & 4 & 0 & 7 & 3.4 \\
\hline 30. Maerua crassifolia & Ekabekebeke & 2 & 0 & 1 & 3 & 1.4 \\
\hline 31. Maerua decumbens & Ereng lokorio & 1 & 0 & 0 & 1 & 0.5 \\
\hline 32. Maerua oblongifolia & Erut & 1 & 2 & 0 & 3 & 1.5 \\
\hline 33. Maytenus senegalensis & Eipa & 0 & 1 & 0 & 1 & 0.5 \\
\hline 34. Paederia pospischillii & Ekaburu & 2 & 0 & 0 & 2 & 1 \\
\hline
\end{tabular}




\section{Continued}

\begin{tabular}{|c|c|c|c|c|c|c|}
\hline 35. Phyllanthus sepralis & Elagama & 2 & 0 & 0 & 2 & 1 \\
\hline 36. Prosopis chilensis & Ekoromwace & 1 & 0 & 0 & 1 & 0.5 \\
\hline 37. Salvadora persica & Etirae & 2 & 4 & 1 & 7 & 3.4 \\
\hline 38. Seddera hirsute & Esekon & 0 & 0 & 1 & 1 & 0.5 \\
\hline 39. Sericocomopsis hildbrandtii & Lomanang & 1 & 0 & 2 & 3 & 1.4 \\
\hline 40. Solanum incanum & Ekabonyo & 2 & 0 & 0 & 2 & 1 \\
\hline 41. Solanum quangulans & Etulelo & 0 & 1 & 0 & 1 & 0.5 \\
\hline 42. Ximenia Americana & Ethikilele & 0 & 1 & 0 & 1 & 0.5 \\
\hline \multirow[t]{2}{*}{ 43. Zizyphus mauritiana } & Ereng erut & 0 & 1 & 0 & 1 & 0.5 \\
\hline & Total & & & & 205 & 100 \\
\hline
\end{tabular}

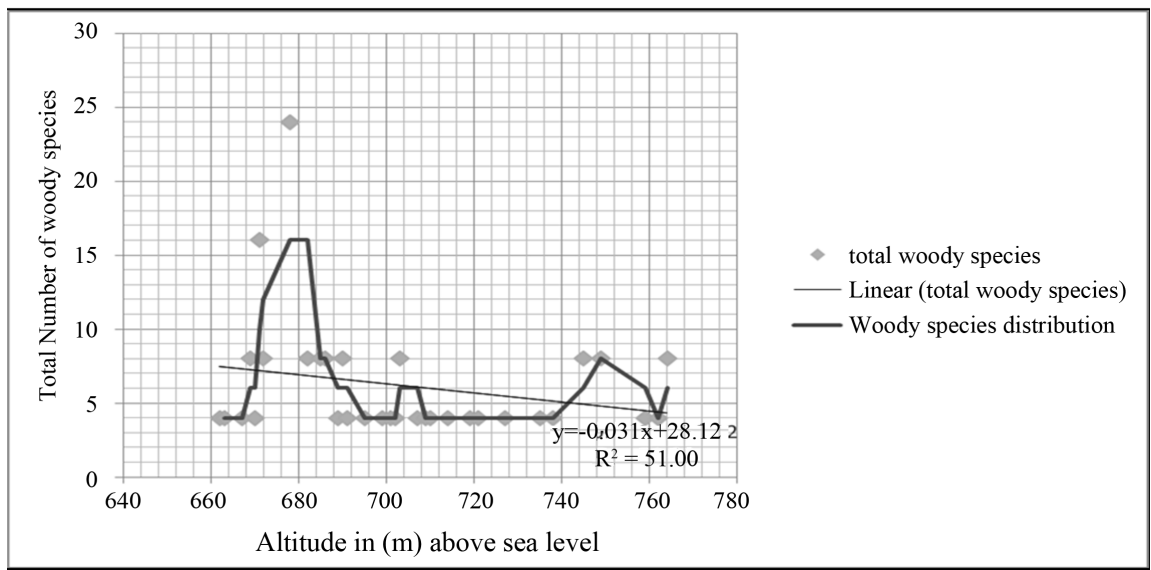

Figure 2. Relationship between Number of woody species and altitudinal gradient.

The overall results showed that 22 percent of the 203 observation sites had woody species addresses between four and five community demands while about 11 percent of the observation sites were able to fulfill up to seven community demands in one site. However, another 12 percent of the sites were only capable of addressing one community demand. The results therefore reflected the multipurpose nature of the woody species in the area which apart from sustaining the backbone livestock sector were also supporting other society needs including medical, energy and shelter needs. The overall pattern indicated that although the peak number of uses for woody species in the area occurred at 680 meters there was a general decline in the number of uses with altitude.

The analysis of the community uses for indigenous woody species showed that the people had a total of 18 demands from the woody vegetation in the area. The demands were mostly in form of consumptive uses (CU) and non-consumptive uses (NCU). The top nine community uses for woody species were: 1 ) fodder (23 percent); 2) traditional medicine (19 percent); 3) firewood (13 percent); 4) household construction (9 percent); 5) wood-carving and wild fruits (8 percent); 6) charcoal (6 percent); 7) house thatching and tobacco flavoring (4 percent) as 
highlighted in Figure 3.

The findings showed that indigenous woody species in the Lokapel area was largely associated with consumptive uses with only three woody species associated with non-consumptive use. For example, thirty six woody species or approximately 83.7 percent were palatable for the livestock consumption thereby making it the most important community use of woody vegetation in the area. The second important use was traditional herbal medicine for which twenty nine species or 67 percent of the woody species were medicinal. This indicated the high dependence by the local people on woody biodiversity for their medical needs due to the lack of modern hospitals. The third major use was firewood which depended on eighteen types of woody species (42 percent) while the fourth and fifth uses involved the consumption of wild fruits from woody species and household construction which depended on thirteen and ten species respectively (Figure 3 ).

Non-consumptive use of woody species was mainly associated with spiritual uses. These included Asparagus sp, Barlearia eranthemoides and Maerua oblongifolia which were considered as a protection against evil spirits crossing into the community area from other villages. It is believed that the above species act as evil spirit arrestors which protect people from their enemies and are therefore conserved and safeguarded for that purpose. A detailed profile of each of the above community uses of woody species is highlighted below.

In the analysis of use of woody species for livestock fodder, it was established that over 70 percent of this use was associated with eleven woody species which comprised Acacia tortilis (12.0 percent), Indigofera clifforrdearia (10.9 per-

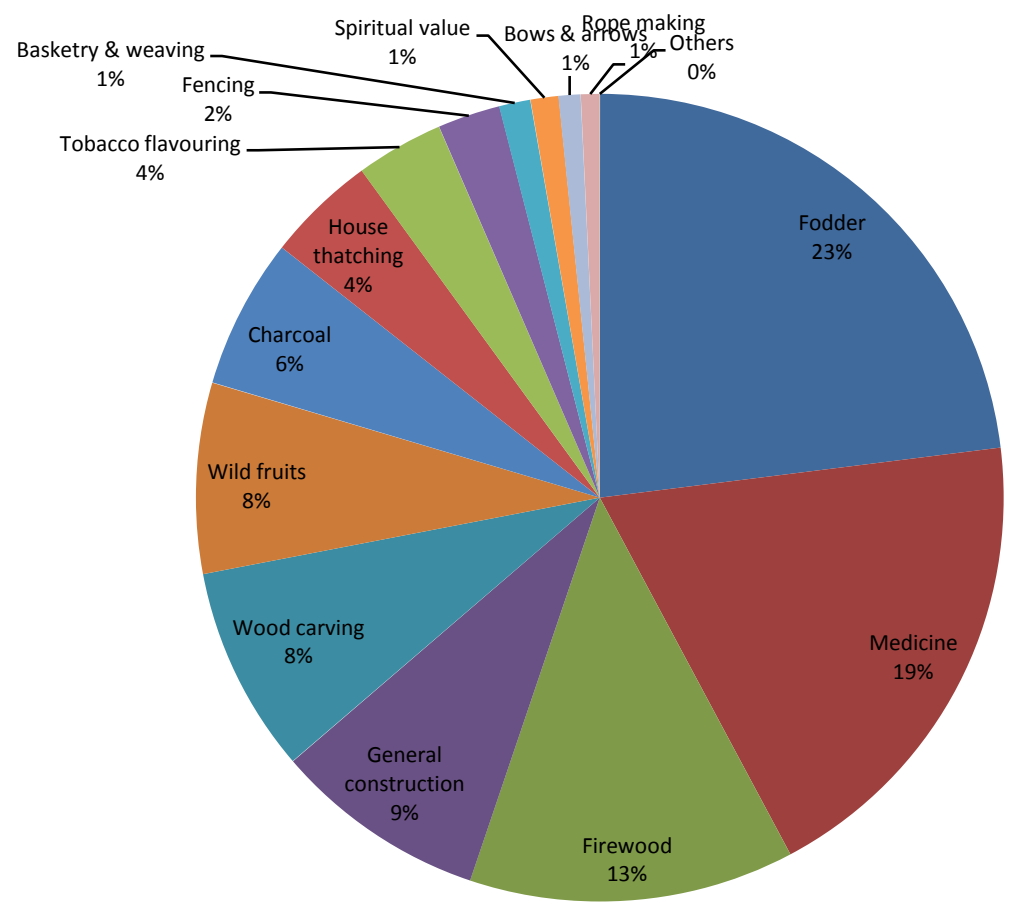

Figure 3. Summary of importance levels for woody species in Lokapel. 
cent), Acacia nubica (9.8 percent), Balanites rotundifolia (7.6 percent), Acalypha fruitcosa (6.0 percent), Acacia reficiens (5.4 percent), Boscia coriascea, (4.9 percent), Lysium europaeum (4.3 percent), Hellotropium longiforum (3.8 percent), Acacia senegal (3.3 percent), and Calotropis procera (3.3 percent). Consequently, goats and camels which are predominantly browsers and not sheep which are mostly grazers dominated the livestock sector in the area. Acacia tortilis was the most important woody species for livestock fodder whose leaves and pods are extracted for goats especially during the dry season.

The fact that the most utilized woody species are still the ones dominating the woody cover indicated that overstocking is not a common problem in the area probably due to the regular decimation of livestock herds by drought. On the other hand, it is likely that traditional conservation strategies include the prevention of direct removal of forage and cutting down of tree and bushes for livestock.

On the other hand, almost 80 percent of the household firewood needs were only dependent on seven species, namely, Acacia tortilis (21.2 percent), Acacia nubica (17.3 percent), Balanites rotundifolia (13.5 percent), Acacia reficiens (9.6 percent), Acalypha fruitcosa (6.7 percent), Acacia senegal (5.8 percent), and Salvadora persica (5.8 percent) Table 3 . Charcoal production was not very common in the area but this energy production was almost exclusively sustained by three woody species which accounted for over 90 percent of the charcoal needs. These were Acacia tortilis (45.8 percent), Balanites rotundifolia (29.2 percent), and Acacia reficiens (20.8 percent).

It was established that over 80 percent of the household construction needs were depended on Acacia tortilis (32.4 percent), Acacia reficiens (14.7 percent), Boscia coriascea, (13.2 percent), Hyphaene compressa (13.2 percent) and Salvadora persica ( 8.8 percent). Similarly, over 80 percent of the house thatching material used in the area was mostly associated with Acalypha fruitcosa (31.4 percent), Hyphaene compressa (25.7 percent), Helliotropium longiforum (20 percent) and Indigofera clifforrdearia (11.4 percent). This form of consumptive utilization can easily affect the abundance of the affected woody species especially due to increasing demand with population growth.

Table 3. A summary of the contribution of woody species in key community needs.

\begin{tabular}{cccccccc}
\hline \multirow{2}{*}{$\begin{array}{c}\text { Key uses of woody } \\
\text { species }\end{array}$} & \multicolumn{6}{c}{ Percentage contribution of commonly used woody species to household needs } \\
\cline { 2 - 8 } & Acacia tortilis & $\begin{array}{c}\text { Acacia } \\
\text { nubica }\end{array}$ & Acacia reficiens & $\begin{array}{c}\text { Balanites } \\
\text { rotundifolia }\end{array}$ & Boscia coriascea & $\begin{array}{c}\text { Hyphaene } \\
\text { compressa }\end{array}$ & $\begin{array}{c}\text { Indigofera } \\
\text { cliffordearia }\end{array}$ \\
\hline Fodder & $12.0 \%$ & $9.8 \%$ & $5.4 \%$ & $7.6 \%$ & $4.9 \%$ & - & $10.9 \%$ \\
Traditional medicine & $14.4 \%$ & $11.8 \%$ & $6.5 \%$ & $9.2 \%$ & $5.9 \%$ & $5.9 \%$ & - \\
Firewood & $21.2 \%$ & $17.3 \%$ & $9.6 \%$ & $13.5 \%$ & - & - & - \\
Charcoal & $45.8 \%$ & - & $20.3 \%$ & $29.2 \%$ & - & $38.9 \%$ & - \\
$\begin{array}{c}\text { Household } \\
\text { construction }\end{array}$ & $32.4 \%$ & - & $14.7 \%$ & - & $13.2 \%$ & & - \\
\hline
\end{tabular}


A total of thirteen species constituting 30 percent of the woody vegetation were considered as edible mostly in form of wild fruits, berries, and nuts. Over 50 percent of the wild fruits were collected from Balanites rotundifolia (23 percent), Boscia coriascea, (15 percent), and Hyphaene compressa (15 percent). This is a critical issue in an area which is associated with food insecurity and frequent famines due to regular drought. In some of the worst droughts the people survive through the use of wild fruits some of which can be quite nutritious.

The other minor uses included use of woody species for domestic and commercial carvings purpose through the making of a wide range of wooden products such as ceremonial stools, domestic equipment such as pans, mortars, pestles, and bowls as well as ornamental curios such as African drums, game sculptures, and masks for the tourism market. Most elderly Turkana men carry small stools which are known as ekicholong which are also used as simple portable chairs. They can be used instead of sitting on the sand in hot conditions and also double as headrests for keeping one's head in an elevated position away from the sand to protect ceremonial head decorations from damage. In Turkana, women are also engaged in the basketry and weaving of baskets, mats and brooms using woody species such as Hyphaene compressa and Zizyphus mauritiana. Calotropis procera is used in the making of ropes for domestic uses. Woody species especially Grewia tenax and Ficus sycamorous are used in the making of bows and arrows for local security. The species which are commonly used in the fencing of the household compound or manyatta are Acacia nubica, Acacia elatior and $Z i$ zyphus mauritiana. The woody species which are used in the making of domestic and commercial carvings are likely to be negatively affected by increasing demands for especially the area becomes more accessible to the national tourist circuits. Other minor uses of woody species in the area included tobacco flavoring using Acacia tortilis and Calotropis procera, traditional tooth brushing using Salvadora persica and milk fermentation.

The ranking of woody species according to their level of importance showed that Acacia tortilis was the most important in addressing different needs of the local community (Table 3 ). The species had twenty two multiple uses, the highest among the woody species identified. The other prominent multipurpose woody species included Balanites rotundifolia, Acacia reficiens, Hyphaene compressa, Acacia nubica, Boscia coriascea, and Indigofera cliffordearia (Table 3). Discriminant function analysis was undertaken in order to determine the distribution of the most valuable woody species at different altitude, whereby the data were subjected to a square root transformation prior to analysis, to reduce positive skewness and stabilize the variances. The analysis showed that the uses of woody species differed significantly at different altitudes beyond the $682-704$ meter range.

The 682-704 $\mathrm{m}$ zone is the zone of peak benefit from the woody species in the Lokapel area. This is contrary to the expected trend of topographic impact whe- 
reby the lower riparian and upper upland zones are usually assumed to have conditions which should support more robust vegetation in terms of both diversity and abundance as a result of favorable hydrological and pedological attributes. The distribution of woody benefits reflected a more distinct hump-shaped pattern with altitude compared to the species-richness pattern.

The findings of the study established that Acacia tortilis, the most useful species was so popular and highly respected by the Turkana people to the extent that a large number of people in the area were actually named " $E$ woI", the local name for Acacia tortilis. The tree was regularly celebrated in song and dance during traditional ceremonies as an appreciation for its role in supporting the people. It was established that Acacia tortilis because of its high value in the area was associated with a rare form of private ownership regime, locally known as "ekwar", which was mostly operating within the communal property regime which characterized most of the resources in the area. In the "ekwar" system, specific owners marked some of the strategic Acacia tortilis trees as well as the best in terms of size, growth form, and location usually by attaching a tall pole against them in order to prevent communal use. This indigenous ownership system therefore allowed individual families the exclusive user rights to resources from certain highly valued trees.

\section{Discussion}

The findings showed that the small scale topographic gradient comprising $100 \mathrm{~m}$ altitude range from $662 \mathrm{~m}$ (River Turkwel) to $764 \mathrm{~m}$ (Lokapel Hills) and a 2 - 4 $\mathrm{km}$ longitudinal stretch demonstrated a peak in woody species number at $680 \mathrm{~m}$ which was in close range to the riparian floodplain environment and not the hill environment. Although the altitude factor accounted for 51 percent of the variation in woody species, it was not strong enough to influence rainfall as a key environmental factor of woody vegetation distribution within tropical drylands. However, a wide range of other environmental attributes especially the soil catena and historical influence of the hydrology by the riparian environment could account for the concentration of woody species near the middle ground area. An example, the extent to which portions of a landscape may differentially capture or retain scarce water and nutrients is an important determinant of vegetation patterns, particularly with respect to the distribution of woody plants [29].

The woody species distribution pattern established in Lokapel was similar to the hump-shaped altitudinal species-richness pattern of [30]. This is has been recorded widely around the world but mainly in large-scale topographic studies [30]. The pattern was established in northern Ethiopia in a study conducted in the highlands of Tigray and lowlands of the Afar region within Great Rift Valley However, the hump-shaped distribution pattern in this study was more distinct for the number of woody uses rather than the number of woody species.

The riverine peak in woody species concentration and their community benefits emphasized the importance of the riparian environment as a source of a wide 
range of woody biodiversity resources. The zone appeared to be environmentally vulnerable due to the resource sharing. It also appeared that the sharing of common property resources in the riparian area can create hotspots for resource oriented-conflicts which has been recorded in other studies [31].

The overall decline in the number of species with increasing altitude indicated that the Lokapel Hill did not have a sufficiently strong environmental command in terms of rainfall and soil characteristics to influence the woody biodiversity as in the case of the Turkwel River. This can be explained by the fact that the study area was located in lowland dryland environment whereby the climatic impact of low-lying hills is minimal.

In terms of woody species utilization, the area can be said to practice sustainable biodiversity use because most of the heavily used woody species were also the most dominant, namely Acacia tortilis, Acacia reficiens, Acacia nubica, Indigofera cliffordearia, Balanites rotundifolia, Hyphaene compressa and Boscia coriascea among others. For example, the most valued woody species for livestock fodder, firewood and charcoal which can be very demanding were associated with Acacia tortilis, Acacia nubica, Acacia reficiens and Balanites rotundifolia which therefore were among the most valued species by the community in terms of their daily needs. However, the utilization did not appear to diminish them in the area as observed on the ground where these were among the top ten in terms of widespread distribution. Other biodiversity studies carried out in the lower and central sections of the Turkwel River identified Acacia tortilis and Hyphaene compressa as the most common woody species [31] [32] [33].

The findings of this study revealed that the Turkana community depends heavily on woody vegetation for diverse uses. It was quiet evident that indigenous woody biodiversity is a key resource that sustains the socio-economic welfare of the local residents in Lokapel. Apart from being the source of fodder for livestock, woody vegetation is utilized for a variety of uses ranging from the provision of household utilities to sustaining human health. Woody species are also commercially exploited and used in the widespread basketry industry in Turkana. The local community has adapted to the local environment by exploiting the woody species that are in high abundance probably as a survival strategy. The study established that Acacia tortilis was the most highly valued and popular woody species that is also highly respected by the Turkana people. It is expected that this could result in higher conservation status for $A$. tortilis compared to other woody species.

The rare woody species such as Indigofera swaziensis (1.8 percent), Zizyphus mauritiana (2 percent), Ximenia americana (2 percent), Maytenus senegalensis ( 2 percent), and Maerua decumbens ( 2 percent) were not associated with any major community uses. Both Lycium europaeum and Salvadora persica were some of the few species whose moderately high frequency at 13.7 percent each was not coupled by a remarkable multipurpose use. However, Salvadora persica was associated with the traditional toothbrush or chewing stick called "Muswa- 
$k "$ which has been used since ancient history especially in India to Africa. Recent studies have indicated that Salvadora persica has beneficial therapeutic properties and a good potential as an effective adaptogenic herbal remedy [34]. Commercial trade in the species was found to be undertaken along the Lodwar-Kapenguria Highway. A study is needed to establish whether that kind of trade could eventually endanger the species in any way.

Indigenous woody vegetation was found to serve as fall-back source of food during the harsh periods of prolonged drought during which famine and starvation are quite common. At least three species were widely utilized for this purpose, namely Balanites rotundifolia, Boscia coriascea, and Hyphaene compressa. A recent study has shown that some woody species which the local people used as a source of wild fruits, berries, and nuts are very nutritious. The Turkana doums palm (Hyphaene compressa), for example was found to have six essential minerals in the mesocarp of the nut of the Turkana doum palm [35]. The mesocarp of the nut contains substantial amounts of proteins and amino acids.

\section{Conclusions and Recommendations}

The study did not find a very strong environmental impact of topographic gradient on the distribution and utilization of woody species because of the small scale nature of altitudinal change. This was attributed to the dominating impact of the widespread lowland environment on climate in the area. This has a strong influence on the configuration of the woody vegetation beyond the influence of the small scale topographic gradient. Consequently, the strong attachment which the local community had on the Lokapel Hills as a key life support ecosystem was probably associated with its hydrological command as a source of storm water during the rains as a result of the $100 \mathrm{~m}$ altitudinal gradient. This flushing effect was magnified by the marginal underground soil cover in the area. These conditions enabled the local people to access water along the laggas generating from the hilltop just like the mountains are a source of precious rivers in dryland areas. The peak in woody species number at $680 \mathrm{~m}$ was probably the reason why the current and previous Lokapel villages were located around that zone. This means that even marginal topographic gradient will influence human settlement patterns in dryland areas by attracting people to locations in close range to the vital resources.

The woody vegetation in the area was a key livelihood asset for the local people with Acacia tortilis, A. reficiens, A. nubica, Balanites rotundifolia, $\mathrm{Hy}$ phaene compressa, Boscia coriascea and Indigofera cliffordearia as the most valued species. However, it is possible that the multiple demands for these species could eventually exacerbate the threat of over exploitation especially within and around village sites. This risk could escalate with increasing population and the collapse of the traditional systems and practices which have safeguarded valued woody over the years.

The following recommendations were generated from the findings and con- 
clusions in the study:

It is necessary to retain the traditional systems and indigenous strategies of conserving valued woody species in dry land environments especially within the landscapes associated with heavy utilization. This includes sustaining the traditional nomadic lifestyles which usually ensure periodic resting and natural recovery of tired landscapes and over utilized species.

It is necessary to explore and encourage the use of woody species that are not in very high demand although that might require a lot of effort for sufficient mindset change.

\section{Acknowledgements}

We would like to acknowledge with gratitude the valuable technical and logistical support that we received from the GoK/UNDP/GEF IVP Project Field Officer Mr. Maina Mwangi for making the necessary arrangements with the local community prior to the commencement of the study. We further extend our sincere appreciation to Mr. Boaz Ekiru who was our technical field assistant. Special gratitude goes to the community of Lokapel led by the area Assistant Chief Mr. Lochii Alakwa, who mobilized the local residents to support the study and also made appropriate security arrangements for the study team. The Funding of the IVP is provided by the Global Environment Facility through the UNDP and UNEP and executed by the Ministry of Environment and Natural Resources on behalf of the Government of Kenya. The National Environment Management Authority was coordinating the technical implementation of the project.

\section{References}

[1] Pratt, D.J. and Gwynne, M.D. (1977) Rangeland Management and Ecology in East Africa. Hodder and Stoughton, London.

[2] Herlocker, D.J. (1999) Rangeland Resources in Eastern Africa: Their Ecology and Development. German Technical Cooperation, Nairobi.

[3] Kabubo-Mariara, J. and Karanja, F.K. (2007) The Economic Impact of Climate Change on Kenyan Crop Agriculture: A Ricardian Approach. Global and Planetary Change, 57, 319-330. https://doi.org/10.1016/j.gloplacha.2007.01.002

[4] Langat, R.K. and Mwangata, J.H.N. (1994) Range Management in Kenya: Progress and Status. In: Herlocker, D., Shaabani, S.B. and Buijott, K.S.A., Eds., Range Management Handbook of Kenya. Volume 1, Government Printer, Nairobi, 11-20.

[5] Day, F.P. and Monk, C.D. (1974) Vegetation Patterns on a Southern Appalachian Watershed. Ecology, 55, 1064-1074. https://doi.org/10.2307/1940356

[6] Busing, R.T., White, P.S. and MacKende, M.D. (1992) Gradient Analysis of Old Spruce-Fir Forest of the Great Smokey Mountains Circa 1935. Canadian Journal of Botany, 71, 951-958. https://doi.org/10.1139/b93-107

[7] Roland, C.A. (2006) Landscape-Scale Gradients in Vegetation in Denali National Park and Preserve: A Summary of Data from 20 Study Areas. National Park Service, Fairbanks.

[8] Geiger, R. (1966) The Climate near the Ground. Harvard University Press, Cambridge. 
[9] Johnson, E.A. (1981) Vegetation Organization and Dynamics of Lichen Woodland Communities in the Northwest Territories. Canada Ecology, 62, 200-215. https://doi.org/10.2307/1936682

[10] Allen, R.B. and Peet, R.K. (1990) Gradient Analysis of Forests of the Sangre de Cristo Range, Colorado. Canadian Journal of Botany, 68, 193-201. https://doi.org/10.1139/b90-026

[11] Shumar, L. and Anderson, E. (1986) Gradient Analysis of Vegetation Dominated by Two Sub-Species of Big Sagebrush. Journal of Range Management, 39, 156-160. https://doi.org/10.2307/3899290

[12] Lusigi, W. (1984) Integrated Resource Assessment and Management Plan for Western Marsabit District, Northern Kenya. UNESCO, Nairobi.

[13] Lusigi, W.J., Nkurunziza, E.R., Awere-Gyeke, K. and Masheti, S. (1986) Range Resource Assessment and Management Strategies for South-Western Marsabit, Northern Kenya. UNESCO-IPAL Technical Report No. D-5.

[14] Fratkin, E. (1991) Surviving Drought and Development: Arial Pastoralists of Northern Kenya. Conflict and Social Change Series, Westview Press, Boulder.

[15] Schwartz, J., Shaabani, S. and Walther, D. (1991) Range Management Handbook of Kenya Volume II-1, Marsabit District. Republic of Kenya, Ministry of Livestock.

[16] Campbell, D.J., Gichohi, H., Mwangi, A. and Chege, L. (2000) Landuse Conflict in Kajiado District, Kenya. Landuse Policy, 17, 337-348.

[17] Haro, G.O., Doyo, G.J. and McPeak, J.G. (2005) Linkages between Community, Environmental and Conflict Management: Experiences from Northern Kenya. World Development, 33, 285-299.

[18] McCabe, J.T. (1990) Turkana Pastoralism. A Case against the Tragedy of the Commons. Human Ecology, 18, 81-104.

[19] Homewood, H., Lambin, E.F., Coast, E., Kariuki, A., Kikula, I., Kivelia, J., Said, M., Serneels, S. and Thompson, M. (2001) Long-Term Changes in Serengeti-Mara Wildebeest and Land Cover: Pastoralism, Population, or Policies? Proceedings of the National Academy of Science, 98, 12544-12549. https://doi.org/10.1073/pnas.221053998

[20] Homewood, K. (1994) Pastoralists, Environment and Development in East African Rangelands. In: Zaba, B. and Clarke, J., Eds., Environment and Population Change, IUSSP, Ordina Editions, Belgium.

[21] Oba, G. (2000) Where the Bulls Fight, It Is the Grass That Suffers-Impact of Border Administration on Drought Coping Strategies of the Obbu Booran during the 20th Century. Journal of Oromo Studies, 7, 87-108.

[22] Oba, G. (2001) The Effect of Multiple Droughts on Cattle in Obbu, Northern Kenya. Journal of Arid Environments, 4, 375-386. https://doi.org/10.1006/jare.2000.0785

[23] Pratt, D.J. (1967) A Note on the Overgrazing of Burned Grassland by Wildlife. E. A. Wild Journal, 5, 178-179. https://doi.org/10.1111/j.1365-2028.1967.tb00775.x

[24] Sernnels, S. and Lambin, E.F. (1996) Impact of Land Use Changes on the Wildebeest Migration in the Northern Part of the Serengeti-Mara Ecosystem. Journal of Biogeography, 28, 391-407. https://doi.org/10.1046/j.1365-2699.2001.00557.x

[25] Deshmukh, I. (1986) Ecology and Tropical Biology. Blackwell Scientific Publications, Oxford. 
[26] Serneels, S., Said, M.Y. and Lambin, E.F. (2001) Land Cover Changes around a Major East African Wildlife Reserve: The Mara Ecosystem (Kenya). International Journal of Remote Sensing, 22, 3397-3420. https://doi.org/10.1080/01431160152609236

[27] Oba, G. (1998) Effects of Excluding Goat Herbivory on Acacia tortilis Woodland around Pastoralist Settlements in Northwest Kenya. Acta Oecologica, 19, 395-404.

[28] Oba, G. and Post, E. (1999) Browse Production and off Take by Free-Ranging Goats in an Arid Zone, Kenya. Journal of Arid Environments, 43, 183-195. https://doi.org/10.1006/jare.1999.0544

[29] Wu, X.B. and Archer, S.R. (2005) Scale-Dependent Influence of Topography-Based Hydrologic Features on Patterns of Woody Plant Encroachment in Savanna Landscapes. Landscape Ecology, 20, 733-742.

[30] Abass, A.M. and Mwaura, F. (2013) Remembering the Drylands of Kenya-Integrating the ASAL Economies in Vision 2030. In: Gona, G. and Mbugua, M., Eds., (Re)Membering Kenya (Volume 2) Interrogating Marginalization and Governance, A Project by Goethe-Institut Kenya, Ford Foundation, Twaweza Communications, 88-111.

[31] Amuyunzu, C.L. (1991) Vegetation Resources of Central Turkana District, Kenya. UNESCO-Turkana Resources Evaluation Monitoring Unit (TREMU), 1-30.

[32] Oba, G. (1991) Vegetation Resources of Central Turkana District, Kenya. UNESCO_Turkana Resources Evaluation Monitoring Unit (TREMU), 31-102.

[33] Stave, J. (1999) Woodland Patterns, Resources Use and Management Strategies in the Lower Turkwel River Flood Plain, North-Western Kenya. MSc. Thesis, University of Oslo, Department of Biology, Norway.

[34] Ahmad, H., Ahamed, N., Dar, J.M. and Mohammad, U.J. (2012) Ethnobotany, Pharmacology, and Chemistry of Salvadora persica. Research in Plant Biology, 2 , 22-23.

[35] Lokuruka, M.N.I. (2007) Amino Acids and Some Minerals in the Nut of the Turkana Doum Palm (Hyphaene coriacea). African Journal of Food Agriculture Nutrition and Development, 7, 1-14. 
Submit or recommend next manuscript to SCIRP and we will provide best service for you:

Accepting pre-submission inquiries through Email, Facebook, LinkedIn, Twitter, etc. A wide selection of journals (inclusive of 9 subjects, more than 200 journals)

Providing 24-hour high-quality service

User-friendly online submission system

Fair and swift peer-review system

Efficient typesetting and proofreading procedure

Display of the result of downloads and visits, as well as the number of cited articles Maximum dissemination of your research work

Submit your manuscript at: http://papersubmission.scirp.org/

Or contact nr@scirp.org 